\title{
ONLINE CONTRACT AND THE ISSUES OF GHARAR AND UNCERTAINTY
}

\author{
Siti Salwani Razali*
}

\begin{abstract}
The use of internet as a medium of communication has widened the scope of contract formation. Sale and purchase activities are held online either for performance of contract through the internet itself or to be performed outside the cyber world. Under Islamic Law there are several areas of uncertainty which will have significant impacts on electronic contracting according to Shariah. This is considered as a very fundamental issue especially in the online contract which implies the non physical presence of the parties. In fact if certain fundamental issues in the online contract are not resolved, then the dominant entry of the principles of gharar (uncertainty) arises, and this will make online contracts in Islamic Shariah not feasible. This article seeks to examine what is actually meant by gharar and how it affects the enforceability of the electronic contract in the Shariah. It also discusses the issue of uncertainty under Common Law with a view to ascertain its implications.
\end{abstract}

Assistant Professor, Kulliyyah of Economics and Management Sciences, International Islamic University Malaysia. 


\section{GHARAR AND ITS IMPLICATIONS ON CONTRACT UNDER THE SHARI'AH}

Literally, gharar implies hazard or risk (khatar or mukhätarah), chance or stake. ${ }^{1}$ In Islamic legal terminology, this is the sale of an article of goods which is not present at hand; or sale of an article of goods, the consequence ('aqibah) or outcome of which is not yet known; or a sale involving risk or hazard where one does not know whether the commodity will later come out to be or otherwise. ${ }^{2}$ The term means that such transactions, which are prohibited in Islam in form, are apparently no different from those prohibited in Islam for deceiving when in reality the nature of the object is not known and therefore risk is involved.

Gharar in contract means the element of uncertainty in the subject matter of a contract or as regards the price of the goods, or any speculative risk. ${ }^{3}$ The presence of gharar in a commercial transaction or in the related contract enables one party to earn material gain at the expense of the other party. There is no agreement among scholars as to the degree of gharar that renders the contract void. Scholars distinguish: a) trifling gharar (gharar al-yasir), element of uncertainty that is acceptable from the point of view of Shariah; b) average gharar (gharar al-mutawassit), the contract can be valid if certain conditions are met; and c) excessive gharar (gharar al-kathir), the presence of which invalidates the contract.

Malik defines bay al-gharar, explicitly as an aleatory transaction. Bay al-gharar, according to him, can be defined as a sale of an object which is not present so that the quality being good or bad is not known to the buyer. These are sales where there is an element of chance. Aleatory sales are common in pre-Islamic times. Eventually, the transaction of algharar is reported to have been banned by the Prophet.

$1 \quad$ According to Schacht, Arabic mukhātarah was attested by medieval Latin as mohatra.

2 Gharar also means risk, peril and uncertainty. The gharar sale is a kind of sale which involves giving an undertaking which the seller is not certain to fulfil.

3 For instance, gharar is present when the seller sells goods that he does not currently possess (fish in water etc.), or if the performance of obligations under an agreement is conditional on the occurrence or non-occurrence of a certain event (fall in currency exchange rate etc). 
Whereas according to Ibn Manẓūr, gharar literally means danger whereby according to al-Qurāfī in his book gharar also means khadī'ah that is cheating. ${ }^{4}$

In a contract of sale, gharar often refers to uncertainty and ignorance of one or both of the parties over the substance or attributes of the object of contract or of doubt over its existence at the time of the contract. Muslim jurists have differed widely over the definition of gharar.

There are various definitions and interpretations of gharar by various prominent Muslim scholars, among them are:

1. According to Sarakhsî: gharar takes place where the consequences (of transaction) remain unknown. ${ }^{5}$

2. According to Ibn Hazm: gharar in sales occur where the purchaser does not know what he has bought and the seller does not know what he has sold. ${ }^{6}$

3. Ibn ' $\bar{A}$ bidinn ${ }^{7}$ defines gharar in the following words: gharar is uncertainty about the existence of the subject-matter of sale. ${ }^{8}$

4. Ibn Qayyim has described gharar as being the subject matter, the vendor is not in a position to hand over to the buyer whether the subject matter exists or not. ${ }^{9}$

$4 \quad$ Some jurists like Qāḍ̄ 'Ayyad said originally gharar is something that superficially shows what you like but actually you hate it. That is why it is said that al dunyā mata' al ghurūr (the worldly life is mere illusion. manipulated without actual awareness of the property being implicated. Taken from the book Al-Qurāfī, al-Furūq, 3 Beirut, Dār al Fikr (1973) p. 266.

5 Al-Sarakhsi, Muhammad al-Mabsūt b. Aḥmad, Maṭba'ah Sa'ädah, Egypt 1372.

6 Ibn Hazm, al-Aḥkām fi Ușūl al-Aḥkām, Egypt, Maṭba'ah Sa'ādah, 1348.

7 Ibn 'Ābidīn, Radd al-Mukhtār 'ala Durar al-Mukhtār, Egypt, Bulaq.

$8 \quad$ Sarakhsi, Al-Kāsāni, Ibn Hazm and Ibn 'Ābidīn, all of them belong to Hanafī school, as regards to the definitions given by them what Ibn 'Ābidīn focused on in his definition is suspicion but Sarakhsi and Kāsāni emphasize more on the uncertainty of the outcome.

9 Ibn Qayyim, I ' lam al-Muwaqqi in 1 Beirut, Dār al Kutub al- 'Ilmiyyah, 358. 
5. According to Ibn Rushd, gharar is to be found in contracts of sale when the seller suffers a disadvantage as a result of his ignorance, with regard to price of the article or the indispensable criteria relating to the contract or its object or quality or time of delivery. ${ }^{10}$

6. Sanhūrīi, ${ }^{11}$ an eminent modern jurist is of the view that lack of knowledge about the material terms of the contract is the distinct feature of a gharar contract. He says that gharar takes place in the following circumstances:

a. when it is not known whether the subject matter exists;

b. if it exists at all, whether it can be handed over to the buyer;

c. when want of knowledge affects the identification of the genus or species of subject matter;

d. when it affects its quantum, identity or necessary conditions; and

e. when it relates to the date of a future performance.

Ibn Taymiyyah makes a clear cut definition and category of gharar when he said that it is of three types. First, bai' ma'düm that is a sale of non existing contract, second bai' sinin, that is the sale of something where the seller can never deliver; and third, bai ' majhūl that is the sale of unknown object. In other words he is saying that gharar is similar to jahālah (lack of knowledge). ${ }^{12}$

Whereas according to Mālikī, gharar in the view of Malik bin Anas is a business contract of not knowing exactly what will be the outcome. ${ }^{13}$ This is quite near to the meaning of gharar according to Shāfi 'i whereby the majority of jurists from Shāfi 'i define gharar as a contract of unknown outcome. ${ }^{14}$

\footnotetext{
10 Ibn Rushd, Bidāyat al-Mujtahid, Mușțafā al-Bābī al-Ḥalabī, Cairo 1370.

11 Sanhūri, Masādir al-Haq, vol. 4, p. 270.

12 Ibn Taymiyyah, Nazariyyāt al- 'Aqd, Beirut, Dār al-' Ilm.

13 Imām Mālik, Al-Muwaț̣a', Vol. 5, Cairo, Maṭba'ah Al-Sa'ādah (1332) H, 42.

14 Al-Shīrāzī, Al-Muhadhdhab, Vol. 1, Cairo, 'Īsa Ḥalabī, 263.
} 
From these definitions we can say that gharar revolves around the issue of a business contract of uncertain outcome, or uncertainty regarding the knowledge of the subject matter of the contract and also the element of jahālah (lack of knowledge) and uncertain end of a contract. In other words, gharar thus includes both ignorance over the material attributes of the subject matter and also uncertainty over its availability and existence. These are the types of gharar which will affect the application of online contracts under the Sharī'ah.

\section{THE RULE FOR PROHIBITION}

In general the Qur'ān explicitly forbids all commercial transactions that involve injustice. ${ }^{15}$ The Prophet has clearly forbidden gharar and jahālah (lack of knowledge) ${ }^{16}$ which in contract is characterized by an unspecified element of quality, quantity or price.

The general principle to avoid gharar in transactions can be concluded from the Traditions, as reported to have been laid down by the Prophet; a contract must not be doubtful or uncertain as far as right and obligations of the parties are concerned. The object of a legal contract, res in commercio must be precisely determined and terms must be clear and known.

In this case the Prophet is reported to have said: "Do not sell a thing which is not with you." ${ }^{17}$ The sale of non-existent and undeliverable goods was common in pre-Islamic times.

Concerning this matter, 'Abdullah ibn 'Abbas prohibited the selling of dates on a palm tree before harvesting them. This means that the transaction was not valid, unless the goods were ready to be delivered. ${ }^{18}$ Zayd ibn Thābit and Zubayr ibn 'Awwām, on the other hand, allowed such transactions. It could be suggested that this second opinion was based on the assumption that the purchaser knew of the existence of the goods and that the vendor would be able to deliver them on the agreed

\footnotetext{
15 Sūrah Al-Nisā’ 4:29.

16 Reported by Muslim, Saḥịh Muslim, vol. 3, p. 56.

17 Reported by Muslim, Saḥịh Muslim, vol. 3, p. 56.

18 Ibn Mājah, Sunan Ibn Mājah, vol. 1, 1372.
} 
terms and at the agreed time. In this case, the purchaser would be aware of the condition of the goods.

It may also be understood that the commodity must be defined and determined and clearly known to the contracting parties. This rule applies to any commodity which can be weighed and measured. A sold commodity is deemed to be sufficiently known to the two parties if they have inspected it, a commodity which is not there cannot be sold, unless both parties have previously seen it. The purchaser has the right of option to refuse to buy it after inspection.

In principle there is no difference of opinion among Muslim jurists about the prohibition of gharar. They prohibit gharar because it affects the subject matter and the price, which can generate unearned profit or an unacceptable loss to the parties to a contract. Hence the motive behind the prohibition of gharar is avoidance of risk in sale. ${ }^{19}$

It is also obvious that with regards to sale transactions, the rational behind the prohibition of gharar is not the existence or non existence of the goods but it is the vendor's obligation to deliver the subject matter of the sale. If he is not in a position to do so, the transaction will be void according to the degree of gharar involved..$^{20}$ For instance the rules laid down to prevent uncertainty in the contract of sale have been applied by analogy to the sale of salam (a sale with advance payment for future delivery) istișna $\bar{a}^{c}$ (contract of manufacture) and ijärah (lease contract). These contracts ought to be considered as invalid but because of economic needs and the public interest these contracts are treated as legitimate transactions in that they fulfil certain specifications despite the non existence of the goods at the time of delivery. ${ }^{21}$

Several reasons were given for the prohibition of bay' al-gharar. Some of them are related to fraud since such a sale amounts to obtaining property of others by selling unavailable goods and the contract may lead to disputes and disagreements between the parties in the contract, or stipulating an agreement to agree, or an agreement in future.

\footnotetext{
19 Amin S. Hasan, Islamic Law in the Contemporary World, Royston Ltd. U.K, 1985, p. 72.

20 Salih, Nabil, Unlawful Gain and Legitimate Profit in Islamic Law, Cambridge University Press, 1986, p. 554.

21 Salih, Nabil, Unlawful Gain and Legitimate Profit in Islamic Law, Cambridge University Press, 1986, p. 554.
} 


\section{THE OPTION OF SIGHT (KHIYĀR AL-RU'YAH) AND BAI' $A L-G H \bar{A}$ 'IB}

The Hanafis are the vanguards of promoting the permissibility of the option of sight in a sale contract. They claimed that the expedient was provided by a hadīth reported from Al-Zurqāni that the Prophet decreed that if a person bought a material which he had not seen, he had the option whether to rescind or endorse the contract upon sighting that material. ${ }^{22}$

Based on this hadith the Hanafis maintain that the sale of an absent subject matter is valid even though the buyer has not been informed by the seller on its character provided that the buyer has this right of option. The Hanafi's furthermore argue that want of knowledge in this particular transaction is trivial (yasira). For example when one says to another "I sell to you all my property which is in this house", the sale is valid because want of knowledge in the sale is trivial and not substantial. ${ }^{23}$

\section{EFFECT OF GHARAR ON CONTRACTS}

Depending on its scale and magnitude gharar may render a contract totally null and void or it may constitute the basis of indemnity and compensation. A slight gharar may on the other hand be deemed to be tolerable in which case its presence would not affect the basic validity of a contract. ${ }^{24}$

However gharar primarily affects commutative contracts meant for alienation of property for consideration such as sale and hire. The effect of gharar on hire is the same as on sale contract. Some points of similarity between the two contracts with regard to the effects of gharar are as follows:

i) 'Urbūn (earnest money) is impermissible in hire as it is unlawful in a sale contract.

Al Zurqānī, Sharh al-Zurqānī, Egypt, Mațba'ah Sa'ādah, 1379. Qāọī Khān, Fatāwa Al-Khāniyya, Egypt, 1865, vol. 2, p. 114. Hashim Kamali, "Uncertainty and Risk Taking (gharar) in Islamic Law," IIUM Law Journal,1999, vol. 7, Number 2, p. 200. 
ii) Both the sale and hiring contracts are not allowed to be made contingent upon some uncertain future event.

The rented utility in a hiring contract should be known and specified in the same way as price and commodity should be known in a sale contract.

iii) It is a condition of a valid sale that its subject-matter should be deliverable. The same rule applies to a hiring contract. As such, the ijärah of a stray animal is not permissible.

iv) The time of ijārah should be fixed. In a deferred payment sale, the time of payment of price should be also fixed.

For example, if in the contract the fixed date for payment is not stated this means that there is uncertainty in the terms of the contract and this will amount to gharar.

The Muslim jurists differ on the effects of gharar on gratuitous contracts. To Mālikī jurists, gharar has no effect on donations. Thus, it is valid to donate escaped animals, or fruits before they ripen. But according to Shāfi 'î̀, Hanafī and Hanbalī jurists, the subject matter of donation should be known and determined. They do not allow the donation of an unborn animal or milk in the udders. As regards to a will, all the jurists are unanimous that it is valid even if the subject matter is nonexistent, undetermined and outside the control of the testator or beneficiary. It is, therefore, permissible to bequest what an animal or a tree will produce. It is also valid to bequest an undetermined portion of property. This testament is treated valid and it is the duty of the heirs to specify that portion.

\section{UNCERTAINTY UNDER COMMON LAW}

Generally under Common Law there are two aspects to the issue of uncertainty. First the language used may be too vague in which case the court is likely to hold that there is no concluded agreement i.e the contract is void for uncertainty. The court needs to be convinced that the alleged contract is expressed in language so obscure and so incapable of 
any definite or precise meaning that it is unable to attribute to the parties any particular contractual intention. ${ }^{25}$

The second aspect is that of failure to reach agreement on a vital or fundamental term of an agreement. In that event the contract also fails for incompleteness though there is no problem with the clarity of the language. An agreement that is unclear and that which is incomplete can shade into one another and brings into misunderstanding between the parties.

The two categories of uncertainty at common law are best summed up in this judicial statement:

"It is a first principle of the law of contract that there can be no binding and enforceable obligation unless the terms of the bargain or at least its essential or critical terms have been agreed upon. So there is no concluded contract where an essential or critical term is expressly left to be settled by future agreement of the parties. Again there is no binding contract where the language used is so obscure and incapable of any precise or definite meaning that the court is unable to attribute to the parties any particular contractual intention”26

From here we may understand that under Common Law uncertainty will arise if there is uncertainty as regards the terms of the contract and also uncertainty regarding the language and the meaning of the terms of the contract.

The Malaysian Law in section 30 of the Contracts Act 1950 provides that:

"Agreements, the meaning of which is not certain or capable of being made certain are void."

If A agrees to sell to B 'a hundred tons of oil' there is nothing whatever to show what kind of oil was intended and thus the agreement is void for uncertainty. ${ }^{27}$

$25 \quad$ See G. Scammel \& Nephew Limited v. Ouston (1941) AC 251 at 268.

26 Menzies J. quoting Sugerman J. from the N.S.W. Supreme Court, Thorby v. Goldberg (1964) CLR 597 at 607.

27 Section 30, Contracts Act, 1950, illustration c. 
But if A is a dealer in coconut oil only, agrees to sell to B one hundred tons of oil, the agreement is not void for uncertainty because the nature of A's trade affords an indication of the meaning of the words. The contract will be construed as one for the sale of one hundred tons of coconut oil. ${ }^{28}$

However if the meaning is unclear but it is capable of being made certain, the agreement is not void for uncertainty. The example can be seen from the illustration below i.e.

\footnotetext{
"A agrees to sell to B one thousand kilos of rice at a price to be fixed by $\mathrm{C}$. As the price is capable of being made certain, there is no uncertainty here to make the agreement void."
}

In the above example if $\mathrm{C}$ refuses or is unable to fix the price only then will the agreement become void.

In Karuppan Chetty v. Suah Thian ${ }^{29}$ the contract was declared void for uncertainty because the parties agreed to a lease of \$35 per month for 'as long as he likes.'

The court is often in an unenviable position when it is called upon to construe an agreement whose terms are somewhat uncertain. On the one hand it does not wish to impose terms not intended by the parties and on the other it tries to imply certain terms to uphold a loosely worded agreement, bearing in mind that people do not always work out the terms of their agreements in meticulous detail. ${ }^{30}$

\section{THE ISSUE OF GHARAR IN THE ONLINE CONTRACT}

One important issue regarding online contracts under ShariÑah is the issue of gharar.The juristic debate over gharar revolves around the question whether it consists mainly of uncertainty over the existence

\footnotetext{
$28 \quad$ Ibid.

$29 \quad$ (1916) 1 F.M.S.L.R. 300.

30 Beatrix Vohrah, Wu Min Aun, The Commercial Law of Malaysia, 2001 at 47 .
} 
of the subject matter of contract or whether gharar basically consists of ignorance of the material attributes of the contract. ${ }^{31}$

As the online contract is considered as an inter absente contract and the parties are contracting without seeing each other and without knowing the real existence of the subject matter and its attributes then the question of gharar will be an issue.

In online contracts, the issue of gharar will arise as there are times whereby we do not know whether the subject matter exists or not, deliverable or not and sometimes the subject matter is presented in description only without being given the true picture of its genus and attributes. Hence it is still necessary to revive the issue to know whether this can affect the validity of the online contract.

After a thorough examination, the types of gharar which are relevant to the online contract are gharar as regards to the existence of the subject matter, and also gharar as regards to the attributes of the subject matter.

According to Hashim Kamali ${ }^{32}$ with reference to a sale of the unseen or sale of what is not visible (bai $\iota^{`}$ ghäib), the schools of law have held different views on the ground basically of their respective perceptions of gharar. Whereas Shāfi ' $\overline{1}^{33}$ considered gharar in bai ' alghā'ib to be fatal, Imām Mālik ${ }^{34}$ viewed it to be negligible. Abū Hanīfah ${ }^{35}$ on the other hand held that there was no issue over gharar as long as the buyer was granted the option of viewing (khiyār ru'yah).

This is somewhat different from the views of Ibn Qayyim ${ }^{36}$ and al-Sanhūr $\overline{1}^{-37}$ when they further categorized the sale of non existent goods into four categories:

$31 \quad$ Hashim Kamali, 1999, "Uncertainty and Risk Taking (Gharar) in Islamic Law,” International Conference on Takaful Insurance, Kuala Lumpur, Hilton, June 2, 1999.

32 Ibid.

33 Al-Shāfi 'ī, Muhammad Ibn Idrīs, al-Umm, Egypt, al-Mațba'ah alAmiriyyah.

34 Imām Mālik, Al-Muwatțā', Vol. 5, Cairo, Maṭba'ah Al-Sa ādah (1332) H, 42.

35 Abū Hanīfah, Musnad al-Imām Abì Hanīfah, 1327.

$36 \quad$ Ibn Qayyim, I' läm al-Muwaqqi 'in, vol. 3, p. 237.

37 Sanhūrī, Mașādir Al-Haqq, vol. 4, p. 270. 
Firstly, when the object existed in the essence but came into completion thereafter; secondly, when the object although non existent at the time of the contract was certain to exist in the future; thirdly, when the object was non existent at the time of the contract, but whose existence in the future was uncertain and fourthly, when the object was non existent at the time of the contract and could not be expected to exist in the future.

Of these four types, only the last two varieties presented situations in which gharar was deemed fatal and therefore invalidated the contract. As for the first two they have both concluded that gharar in them was negligible and the sale in both cases was consequently valid.

This is supported by Mohammad Șiddiq Al-Dhorīir ${ }^{38}$ when he holds a similar view in saying that a sale of the non existent is unlawful if its future prospects are totally unknown but that sale is valid if it is certain that they will exist in the future.

This situation is basically consistent with the common law rules of Sale of Goods. In fact in section 6 of Malaysian Sale of Goods Act 1957, it provides for the categories of goods which is existing or future goods which become a valid subject matter to a contract. Section 6(1) provides that:

"The goods which form the subject of the contract of sale may be either existing goods, owned or possessed by the seller or future goods"

According to Ibn 'Ābidīn, the opinion of Muslim Jurists are divided regarding the requirement of the description of the subject matter. Hanafī Jurists are of the view that the description of subject-matter is not necessary as long as it is present and visible for the buyer. But if the subject matter is not visible, its description is necessary. Some Hanafī jurists disagree with this view and hold that description is not necessary as long as the right of inspection is established for the buyer. By exercising this right he can reject the object if it does not correspond with the description. But the proponents of description do not accept this argument. They say that the right of inspection is given to the buyer only to remove trivial uncertainty, not the excessive one resulting from leaving a thing 
undescribed. An invisible object, therefore, should be described at the time of the contract, and if some uncertainty still remains, it may be removed by the exercise of the right of inspection. ${ }^{39}$

Mālikī jurists regard description of subject-matter obligatory irrespective of the fact that it is present or absent, visible or invisible. ${ }^{40}$

Three opinions are attributed to Shāfi ' $\overline{1}$ jurists: First: the sale is not valid until a detailed description is given as in a salam sale. Second, the sale is not valid until relevant attributes are mentioned. Third, the sale is valid even without mentioning the attributes of the object as long as the buyer has a right of inspection.

The Hanbali jurists maintain that the sale of an object with unknown attributes is not permissible.

Regarding this issue, Ahmad Hidayat Buang ${ }^{41}$ further stressed that gharar occurs in the sale contract when the seller fails to describe the character of the subject matter. This non description of the character of the subject matter normally occurs when it is absent ( $\left.g h \bar{a}^{\prime} i b\right)$ in the session of the contract (majlis al- 'aqd) as the need for the seller to describe the character of the subject matter mainly arises in this situation. It can also occur if the buyer has no fair opportunity to see and inspect the subject matter, even if the subject matter is present in the session of the contract. For if the sale is concluded in the darkness of night where the buyer has no opportunity to see and inspect the character of the object, such a contract is said to be void for want of knowledge in its character.

Under Common Law, the sale by description is also valid provided that the goods delivered later must correspond with the description given earlier. This is stated in section 15 of Malaysian Sale of Goods Act 1957 which provides that:

"Where there is a contract for the sale of goods by description there is an implied condition that the goods shall correspond with the description and if the sale is Imām Mālik, Al-Muwattā', Vol. 5, Cairo, Mațba'ah Al-Sa ādah (1332) H, 42.

$41 \quad$ Ahmad Hidayat Buang (2000), Studies in the Islamic Law of Contracts - The Prohibition of Gharar, p. 117, ILBS, Kuala Lumpur. 
by sample as well as by description it is not sufficient that the bulk of the goods corresponds with the sample if the goods do not also correspond with the description."

After looking through the various opinions and views from the Madhhabs and the contemporary jurists it is best to adopt the views from Ibn Qayyim and Al-Sanhūrī who have made a systematic category for the sale of the non existent goods. In this case the issue of gharar can be finally identified and those two categories which are considered as fatal only will affect the legality of the online contract.

In online contracts it is best if we can hold that three conditions must be fulfilled as regards to the subject matter prior to the conclusion of the contract, to reduce and eliminate gharar. Firstly, the goods must be viewed through the screen of the computer and if this is not met then there must be a detailed description of the subject matter which can be read and understood clearly by the contracting parties Then, if this is also not met, the buyer should be given the right of Khiyār al-Ru'yah (option of viewing or inspection).

If the requirements are met, then only the possibility of gharar will be reduced or even eliminated totally especially with the right of Khiyār al-Ru'yah or inspection. Adopting Hanafī school as regards to this three requirements would result in the issue of gharar not becoming a major issue anymore especially in online contracts. In fact, we can see that there is not much difference with the rules under Islamic law as regards to these requirements compared to the position of the subject matter under the Common law rules on sale of goods. Both laws provide the right for inspection to the contracting parties in order to avoid future disputes or in other words to eliminate the element of gharar in the online contract. 